\title{
Discriminant Profile of Young Internet Dependents: The Role of Family Relationships ${ }^{1}$
}

\author{
Michele Terres-Trindade ${ }^{2}$ \\ Universidade do Vale do Rio dos Sinos, \\ São Leopoldo-RS, Brazil
}

\author{
Clarisse Pereira Mosmann \\ Universidade do Vale do Rio dos Sinos, \\ São Leopoldo-RS, Brazil
}

\begin{abstract}
International studies have shown effects of family relations on Internet addiction in young people. This research aimed to outline a discriminant profile of young people classified as dependent and not dependent on the Internet regarding to sociobiodemographic variables to parenting practices, parent-child conflict and interparental conflict. The sample consisted of 200 students (152 girls and 48 boys), between 15 and 24 years of age, 85.5\% reside in Rio Grande do Sul and 14.5\% in other Brazilian states. Participants responded individually to the protocol available online. The results showed that interparental conflict, parentchild conflict and the educational practice of supervision of paternal behavior discriminate dependents on Internet. The educational practice of maternal emotional support was the only discriminating variable for non-dependents. These national findings corroborate the international context studies and reinforce the importance of including the family in promotion and prevention of mental health of young people.
\end{abstract}

Keywords: Internet (addiction), parenting style, parent child relations, marital conflict, family relations

\section{Perfil Discriminante de Jovens Dependentes de Internet: O Papel das Relações Familiares}

\begin{abstract}
Resumo: Estudos internacionais têm apontado repercussões das relações familiares na dependência de internet em jovens. Esta pesquisa buscou traçar um perfil discriminante de jovens classificados como dependentes e não dependentes de internet em relação às variáveis sociobiodemográficas, práticas educativas parentais, conflito pais-filho e conflito interparental. A amostra foi constituída por 200 jovens, com idades de 15 a 24 anos, 85,5\% residentes no Rio Grande do Sul e 14,5\% em outros estados brasileiros. Os participantes responderam individualmente ao protocolo disponível on-line. Os resultados mostraram que o conflito interparental, o conflito pais-filhos e a prática educativa de supervisão de comportamento paterno discriminam os dependentes de internet. A prática educativa de apoio emocional materno foi a única variável discriminante para os não dependentes. Esses achados do contexto nacional corroboram estudos internacionais e reforçam a importância da inclusão da família nas ações de promoção e prevenção à saúde mental dos jovens.
\end{abstract}

Palavras-chave: Internet (dependência), estilo parental, relações pais-criança, conflito conjugal, relações familiares

\section{Perfil Discriminante de Jóvenes Dependientes de Internet: el Papel de las Relaciones Familiares}

\begin{abstract}
Resumen: Estudios internacionales señalan las repercusiones de las relaciones familiares en la dependencia de Internet en jóvenes. Esta investigación trazó un perfil discriminante de jóvenes clasificados como dependientes de Internet en relación a variables sociobiodemográficas, prácticas educativas parentales, conflicto padres-hijos y el conflicto interparental. La muestra fue compuesta por 200 jóvenes (152 niñas y 48 niños), con edad de 15 a 24 años, 85,5\% con domicilio en Rio Grande Del Sur y 14,5\% en otras provincias brasileñas. Los participantes respondieron individualmente al protocolo disponible online. Los resultados mostraron que el conflicto interparental, el conflicto padres-hijos y la práctica educativa de supervisión de comportamiento paterno discriminan los dependientes de Internet. La práctica educativa de apoyo emocional materno fue la única variable discriminante para los dependientes. Estos hallazgos del contexto nacional corroboran estudios internacionales y refuerzan la inclusión de la familia en las acciones de promoción y prevención de la salud mental en jóvenes.
\end{abstract}

Palabras clave: Internet (dependencia), estilo parental, relaciones padres-niños, conflicto marital, relaciones familiares

\footnotetext{
${ }^{1}$ Paper derived from the first author's master's thesis under the second author's supervision, defended in 2014 in the Graduate Program in Clinical Psychology at Universidade do Vale do Rio dos Sinos.

Support: Coordination for the Improvement of Higher Education Personnel (CAPES).

${ }^{2}$ Correspondence address:

Michele Terres-Trindade. Avenida Iguaçu, 119/405, Petrópolis. CEP 90470430. Porto Alegre-RS, Brazil. E-mail: micheleterres@hotmail.com
}

Nowadays, the Internet is undoubtedly a widely used tool for network communication that has reached practically all social classes and age ranges (Center for Studies on Information and Communication Technologies [CETIC], 2013). In addition, it has offered countless political, economic and social benefits. Paradoxically, the benefits related to the increased access to the Internet have acted as facilitators for the harmful use of this technology, appointing the emergence of a new psychopathological condition. The main 
characteristics that can indicate dependence or problematic use of the Internet include the excessive or uncontrolled concern with the Internet (need to stay connected to the net), making the person suffer and/or compromising his/her social, professional activities or other important areas (Ang, Chong, Chye, \& Huan, 2012; Young \& Abreu, 2011).

As it is not acknowledged in any diagnostic classification system and as there is no consensus among the authors about the terminologies related to the harmful use of the Internet, different terms have been used in the literature to designate that condition (Abreu, Karam, Góes, \& Spritzer, 2008; Araújo et al., 2010). The following can be highlighted: Internet addiction (Young, 1998), problematic Internet use (Shapira et al., 2003), Internet use disorder (American Psychiatric Association [APA], 2012), among others. Nevertheless, the expression Internet addiction is the most commonly used (Byun et al., 2009), and was therefore adopted in this research. Conceptually, Internet addiction is an obsessivecompulsive spectrum disorder that covers the connected and/ or disconnected computer use (Dell'Osso, Altamura, Allen, Marazziti, \& Hollander, 2006).

Although Internet addiction is not officially considered a psychopathology, different studies have been conducted to characterize and identify its prevalence in the population. Weinstein and Lejoyeux (2010) undertook a research in the databases Medline and PubMed to review the international literature published between 2000 and 2009 about the diagnosis, the phenomenology, the epidemiology and the treatment in Internet addiction. The results include articles with different established criteria for the diagnosis of Internet addiction and a prevalence rate in the European and North American population ranging between $1.5 \%$ and $8.2 \%$. In the Far East, where technology access is more intense and which concentrates most research on the theme, prevalence rates between $5.52 \%$ and $20.3 \%$ were appointed in young people. As predictive variables, the reviewed studies indicated personality traits, alcohol use, social anxiety and family factors.

Another study undertaken in 11 European countries, involving 11,956 adolescents with a mean age of 14.09 years $(S D=0.89)$ aimed to assess the prevalence of the problematic (Internet addiction) and maladaptive (considered as harmful Internet use in the study, but without some criteria sufficient to classify it as dependence) use among the adolescents. The results indicated a prevalence rate of $4.4 \%$ for problematic use and $13.5 \%$ for maladaptive use, according to the criteria of the Internet Addiction Diagnostic Questionnaire (Young, 1998). Among the female adolescents, higher rates were found for maladaptive use than among the male adolescents, who indicated a higher percentage for problematic use. The factors associated with Internet dependence were: low parental involvement, unemployment of parents/caregivers and living without one of the biological parents (Durkee et al., 2012).

In view of the divergences appointed in the literature, the reason why most of the international studies are still aiming to define the criteria that best describe this phenomenon is perceived, as well as its prevalence in the population (Beard \& Wolf, 2001; Shapira et al., 2003). In countries like South Korea and China, however, research has advanced beyond the diagnosis and prevalence, aiming to consider the factors involved in the emergence and treatment of Internet addiction, which is increasing in these countries' youth population (Yen, Yen, Chen, Chen, \& Ko, 2007).

In that sense, in view of the lack of conceptual precision in the definition of Internet addiction, a theoreticalmethodological heterogeneity is identified in the investigation of the phenomenon, which particularly advocates the psychopathology and justifies research in Brazil focused on the aspects involved in the establishment of Internet addiction, as precise prevalence data in the Brazilian population remain unknown. In addition, considering that Internet addiction is associated with countless emotional and social losses, especially in the adolescent and young adult phase, it becomes even more relevant to study the variables involved in dependence in this population, which is the most exposed to Internet use (Yen et al., 2007; Young \& Abreu, 2011).

Surveying and characterizing the risk and protection factors for the development of psychopathologies in childhood and adolescence involves the study of family relations. A consensus exists in the literature that the family can act as a protection as well as a risk factor in the child development process (Mosmann, Wagner, \& Sarriera, 2008). Research indicates that, in the long term, high levels of marital and family conflicts, in addition to punitive, coercive and inconsistent educational practices among the parents are associated with internalizing and externalizing symptoms in children and adolescents (Cummings \& Davies, 2011; Wagner, 2011), making it pertinent, in a causal link, to question whether these marital and family variables are also associated with Internet addiction in young people.

Among the family variables related to the parentschild dimensions, conflict basically emerges in the literature to indicate two different types of results. On the one hand, there are results that highlight the favorable aspects of this interaction, demonstrating that the parents-child conflicts have a positive function and can contribute to gain autonomy, exchange experience and increase tolerance among generations (Bernedo Muñoz, Fuentes Rebollo, \& Fernández Molina, 2005; Jiménez \& Delgado, 2002; Wagner, Falcke, Silveira, \& Mosmann, 2002). On the other hand, the conflicts are considered negative when they imply the emergence of emotional, social or behavioral problems and reduce the level of satisfaction and family cohesion (Goulart \& Wagner, 2013; López Larrosa, Sánchez Souto, \& Ruíz de Alda, 2012; Luna Bernal, 2012).

In the same way as the parents-child conflict can be associated with positive and negative outcomes in the children's adjustment, the parents' educational practices reflect in the young people's psychosocial development and can permit the acquisition of competences that are necessary and important for this phase or, on the opposite, can be associated with the emergence of different emotional and behavioral problems. The literature appoints that the educational practice that predict externalizing problems, with positive practices - such as emotional support and incentives towards autonomy - serving as protection factors and negative practices - such as intrusiveness and punitive 
control - serving as risk factors for these problems (García Linares, Cerezo Rusillo, de la Torre Cruz, de la Villa Carpio Fernández, \& Casanova Arias, 2011; Paiva \& Ronzani, 2009).

Besides the family variables related to the parents-child dimensions, the marital variables, especially marital conflict, have been significantly associated with the children's psychological symptoms (Wagner, 2011). When investigated from the children's perspective, this dimension is called interparental conflict. According to Cummings and Davies (2011), the children are the most reliable information sources about the constructive or destructive form of the marital conflict when compared to the parents. Destructive conflicts, characterized when the children perceive that the parents do not reach any agreement, have been the most studied, as their negative impact on the family relations is stronger (Goulart, 2012).

The literature demonstrates that interparental conflicts greatly affect the children, as they entail more punitive and coercive educational practices, as well as higher levels of conflicts between parents and children (Benetti, 2006; Erel \& Burman, 1995; Mosmann, 2007; Mosmann et al., 2008). This effect can be explained by the so-called spillover hypothesis (Erel \& Burman, 1995) - which is based on the idea of a positive relation between the quality of the marital relationship and the relationship between parents and children. Thus, the way the marital relations are established entail consequences that spillover and affect the relation between parents and children. In addition, in view of unsolved marital conflicts between the parents, the children can take a position of confrontation as well as distraction. In the attempt to deviate the parents from their focus of tension, they become the center of their attention, displaying symptoms. The children's movement in the attempt to mitigate or deviate the focus of the marital conflicts is called triangulation and has been classically described in Minuchin (1990).

In general, some of the variables associated with these interactions have appeared in international studies, indicating a relation with Internet addiction in young people, specifically parental practices, conflict between parents and adolescents, communication, cohesion and family violence (Chen, Weng, $\mathrm{Su}, \mathrm{Wu}, \&$ Yang, 2003; Parque, Kim, \& Cho, 2008).

Some international studies also appoint relations between specific parenting practices for Internet use and Internet addiction (Lin, Lin, \& Wu, 2009; Liu \& Kuo, 2007). In a study undertaken in the Netherlands among 4,483 public and private school students between 11 and 15 years of age, which was aimed at investigating the correlation between specific parenting practices for Internet use and compulsive Internet use among adolescents, the results indicated that the quality of the parents' communication about the use of the web is an effective tool to avoid its compulsive use. In addition, it was appointed that parents who pay attention to their children's Internet use can impede the development of compulsive Internet use (van Eijnden, Spijkerman, Vermulst, van Rooij, \& Engels, 2010).

Thus, although some aspects of the family relationships, such as parenting practices, the child-parent relationship and the parental marital relationship figure in the international context, demonstrating relations with Internet addiction, the limited Brazilian research is not focused on this aspect, but on the psychopathological phenomenon and its treatment (Abreu et al., 2008; Conti et al., 2012; Pujol, Alexandre, Sokolovsky, Karam, \& Spritzer, 2009). Similarly, no consensus has been reached on the identification of what family variables are more expressive in these interactions, as well as the role of each variable. Also, it is observed that the studies found measure the family variables globally. Without the investigation of specific variables, the results presented are imprecise and lack further research ( $\mathrm{Li}$, Garland, \& Howard, 2014).

In that sense, as Internet access and use among young people are increasing day by day and considering that different dimensions of the family relations are involved in Internet addiction in this population in other cultural contexts, the goal in this study was to outline a discriminant profile of young people classified as dependent and non-dependent on the Internet, considering the socio-biodemographic variables, educational parenting practices, parent-child conflict and interparental conflict.

\section{Method}

This is an exploratory, descriptive and comparative quantitative and cross-sectional study.

\section{Participants}

The participants were 200 young people (152 girls and 48 boys) between 15 and 24 years of age (Brasil, 2005) who lived with at least one of their parents. In this group, $85.5 \%$ $(n=171)$ lived in the state of Rio Grande do Sul and 14.5\% $(n=29)$ in 12 other Brazilian states.

\section{Instruments}

Socio-biodemographic questionnaire. Information was collected with regard to age, sex, education, number of siblings, family configuration, among others.

Internet Addiction Diagnostic Questionnaire. The IADQ (Young, 1998, translated by Young \& Abreu, 2011) consists of eight questions that conceptualize the diagnostic criteria for Internet addiction and assess the non-essential use of the computer/Internet (involving work/study) in the course of the last six months. The criteria are assessed using yes or no answers, resulting in a score between zero and eight. The scoring method of the questionnaire classifies the gravity of the Internet dependence in three distinct dimensions: nondependent ( $0-2$ points), risk of dependence (3-4 points) and Internet dependent (5-8 points) (Durkee et al., 2012). The internal consistency analysis of the tool in an international study (Dowling \& Quirk, 2009) indicated $\alpha=.72$ and, in this study, the coefficient of the total IADQ was $\alpha=.60$.

Scale of Parenting Practices (EPP). Developed by Teixeira, Oliveira and Wottrich (2006), the scale aims to identify the educational parenting practices as the children perceive them and consists of 27 items and six dimensions, measured on a five-point Likert scale. In this study, Cronbach's alpha for the complete EPP corresponded to .93 . 
Parent-Child Conflict Scale (PCC). Originally developed by Buehler and Gerard (2002) and adapted by Mosmann (2007) to assess the level of marital conflict. In this study, the tool was adapted to assess the level of the subjects' conflict with their parents, answered separately for the father and mother. The subscale called Conflicts-disagreements consists of six items that refer to how frequently the subjects experienced disagreements from their parents and are measured on a six-point Likert scale. Higher scores represent high levels of conflict (Buehler \& Gerard, 2002). Cronbach's alpha for the total PCCS in this study corresponded to .75 .

Children's Perception of Interparental Conflict Scale (CPIC). This scale (Grych, Seid, \& Fincham, 1992), translated and adapted by the Dynamic Research Group of Family Relations at Universidade Federal do Rio Grande do Sul, was developed to assess the children's opinions about different aspects of their parents' marital conflict. It consists of 50 items, measured on a five-point Likert scale, subdivided in nine subscales, which describe the dimensions of the marital conflicts as perceived by the children, the children's reaction or interpretation of the conflicts and, finally, the probability of the child's involvement in the marital conflict. Cronbach's alpha for the CPIC in this study equaled .94.

\section{Procedure}

Data collection. The data were collected between March and June 2013. To access the sample, two methods were used, practiced according to the participants' age. To select the participants over age (18 years or older), the snowball sampling technique was used (Faugier \& Sargeant, 1997), which involves successive indications of participants. In this study, the technique was applied through e-mail invitations and a social network. To get access to the participants under age, the convenience choice criterion was adopted, through invitations in schools located in Metropolitan Porto Alegre (RS).

To collect data from the participants over 18 years of age, a link to the website with research information was disseminated by e-mail and through the social network Facebook, using the contact list of the researchers responsible for the study. As different social network users shared the research link, the snowball effect was achieved.

When they clicked on the on-line link, the participant had access to the presentation of the research and researchers, information on ethical aspects, the inclusion criteria and how to participate in the research. Users who accepted to participate in the study should confirm their participation by informing an e-mail address, in order to receive a copy of the Informed Consent Form (ICF), and by clicking on a button to declare their acceptance to participate in the research. On the next screen, the participants accessed the electronic form that contained the questions from the research tool.

Participants under age (between 15 and 17 years) were accessed through contact with public and private schools located in Metropolitan Porto Alegre/RS. The researchers contacted the school boards and presented the research, objectives and how the target students would participate. After the schools accepted, the classes were visited and the students were invited to participate in the study. Students who accepted were asked to have one of the parents/responsible caregivers sign the Informed Consent Form (ICF). Only those students who returned the ICF signed received a password and the website to answer the research tool on-line.

The site to collect data from the participants under age was identical to the participants over age, except that the password was added. Participants who answered the tool but did not comply with the inclusion criteria were excluded from the database.

Data analysis. The analyses were developed in the software SPSS Statistics (Statistical Package for the Social Sciences) version 18.0 and significance was set at $5 \%$ (p $\leq$ .05 ). The psychometric properties (reliability and convergent validity) of each tool were assessed. The statistical treatment of the data consisted of descriptive analyses (means, standard deviations and percentages). Discriminant analysis is used when the dependent variable is dichotomous, in this case the groups dependent and not dependent on the Internet, and aims to understand the differences between the groups and forecast the probability of participants being driven towards one or the other group (Hair, Anderson, Tatham, \& Black, 2005).

\section{Ethical Considerations}

This study received approval from the Research Ethics Committee at Universidade do Vale do Rio dos Sinos (UNISINOS) under protocol no. 187.637, and complied with all guidelines and regulatory standards for research involving human beings.

\section{Results}

First, descriptive analyses were applied to characterize the participants and their families, as well as to identify the participants belonging to the group characterized as dependent on the Internet. The young people were classified according to the IADQ score as dependent and not dependent, excluding those with a score indicating risk of dependence on the Internet. This procedure was adopted in view of the research objective and the criteria of the scale, which classify the risk of dependence as a set of indicators that is not sufficient yet to be considered either dependent or not dependent. After the exclusion, the sample distribution was organized as follows: $84.3 \%$ of the participants not dependent on Internet $(n=123)$ and $15.7 \%$ dependent $(n=23)$.

Among the young people who participated in this study $(N=146), 77 \%$ were female $(n=112)$ and $23 \%$ male $(n=$ $34)$ and the mean age found was $20.25(S D=2.73)$. The participants' education level was distributed among: $71 \%$ undergraduate $(n=104), 23 \%$ secondary school $(n=34)$ and $6 \%$ graduate $(n=8)$, with $82 \%$ coming from private $(n=120)$ and $18 \%$ from public institutions $(n=26)$.

Concerning the participants' family characteristics, $66 \%$ had one or two siblings $(n=96), 18 \%$ were an only child $(n=$ 27 ) and $16 \%$ had three or more siblings $(n=23)$. The family constitution was distributed as follows: $66 \%$ nuclear families $(n=96), 21 \%$ single-parent families $(n=31)$, being $91 \%$ 
female and $9 \%$ male, $8 \%$ extended family $(n=12)$ and $5 \%$ reconstituted families $(n=7)$. The perceived social class the participants informed was classified as $49 \%$ middle $(n=71)$, $26 \%$ upper middle $(n=38)$ and $25 \%$ lower middle $(n=37)$.

Next, discriminant analysis was performed, considering the youth's socio-biodemographic data (sex, age and education) as independent variables and the dimensions of the educational parenting scales (EPP), parent-child conflict (PCC) and perceived interparental conflict (CPIC), assessed separately for father and mother. As the dependent variable, the groups of dependent and non Internet dependent children were considered. These variables produced a discriminant function for the maternal data and another for the paternal data, analyzed separately. Function 1 (Maternal) showed an eigenvalue 0.329 , canonic correlation $0.497, \lambda$ Wilks 0.753 , $X^{2} 38.079$ and $p=.009$. Function 1 (Paternal) indicated an eigenvalue 0.289 , canonic correlation 0.473 , $\lambda$ Wilks 0.776 , $X^{2} 33.993$ and $p=.026$.

The final capacity of the function to correctly classify the subjects in their group is also important from the statistical viewpoint (Hair et al., 2005). In that sense, the function obtained for the maternal variables correctly classifies $80.1 \%$ of the participants in their respective groups and the parental discriminant function distributes $75.3 \%$ of the cases. Thus, as there are two discriminant groups (dependent and not dependent on the Internet), the expected correct random classification corresponded to $50 \%$ for each group. Hence, $80.1 \%$ for the maternal and $75.3 \%$ for the paternal variables appoint satisfactory predictive classification indices, showing that more than half of the young people in this sample were correctly classified in the discriminant profile, considering both the maternal and paternal variables.

Next, Table 1 presents the structural matrix that indicates what variables have a higher weight in the ability to discriminate between the participants dependent and not dependent on the Internet (function 1), with regard to the most relevant maternal and paternal variables. The variables are ranked in absolute correlation order in the structural matrix, with the cut-off point superior to 0.20 (Hair et al., 2005). The signal in the correlations indicates the favorable sense for one group or the other.

\section{Discussion}

The young people who participated in this study are predominantly female, taking undergraduate programs at private universities, belonging to nuclear families (consisting of father-mother-children), middle class, living in cities in Rio Grande do Sul. According to data from the Brazilian Institute of Geography and Statistics [IBGE] (2012), almost half of the Brazilian families (49.4\%) consist of couples with children, indicating that the research sample presents this characteristic close to what is found in the general population. Concerning the larger number of female participants, this can be analyzed based on the way the sample was constituted: through successive indications on a social network. According to data by CETIC (2013) in the Research on the Use of Information and Communication Technologies in Brazil, female youth between 16 and 24 years of age are the majority among Internet users who participate in relationship sites, such as Facebook.

The prevalence of Internet addiction among the participants is noteworthy (15.7\%) and can be compared to rates in Far Eastern countries reaching 20.3\%, to the detriment of Europe and the United States, with rates between $1.5 \%$ and $8.2 \%$ (Weinstein \& Lejoyeux, 2010). As most of the sample is taking undergraduate programs, the literature appoints that Internet use for academic ends places higher education students in the risk population category to acquire Internet addiction related behaviors (Young \& Abreu, 2011). When specifically considering the prevalence data in this sample, however, it should be highlighted that the results found here cannot be discussed in comparison with other Brazilian data, as no other research presenting this information was found.

The analyses permit the achievement of the main

Table 1

Structural Matrix of Function 1: Correlations Among Maternal and Paternal Discriminant Variables and Standardized Discriminant Function

Function 1

Variables

Maternal Paternal

Feeling of Threat of Interparental Conflict

.413

Conflict-disagreements (mother)

Educational Emotional Support Practice (mother)

$-.332$

Perceived Content of Interparental Conflict

Triangulation in Interparental Conflict

.246

Feeling of Threat of Interparental Conflict

Conflict-disagreements (father)

Perceived Content of Interparental Conflict

Educational Practice of Behavior Supervision (father) 
objective, outlining a discriminant profile of the young people classified as dependent and not dependent on the Internet. According to the children's perception of their conflicts with their parents, educational parenting practices and interparental conflict, different functions were obtained, which included variables specifically related to the mother, the father and the couple.

When analyzing the so-called maternal variables only, conflict/disagreements between mother and child are discriminant for Internet addiction, indicating agreement with the literature that appoints high rates of conflict between parents and children among the Internet addicts (Yen et al., 2007). It is known that, in the adolescent and young adult phase, conflicts between parents and children increase, mainly those related to the children's daily activities, such as housework and studying (Jiménez \& Delgado, 2002; Luna Bernal, 2012). This increase in disagreements with the mother can emerge because she is still generally appointed as the main responsible for family care activities, especially for the children (Wagner et al., 2002).

The educational practice maternal emotional support was the sole discriminant variable for the participants who were not dependent on the Internet and seems to serve as a protection factor against dependence. This result reflects the observations in the literature about externalizing problems, which are negatively associated with positive educational parenting practices (Mosmann et al., 2012). In addition, this information supports other studies in which the children appoint the mothers as closer and more affective when compared to the fathers (Linares et al., 2011; Wagner et al., 2002).

Among the specifically paternal variables, the educational parenting practice of behavioral supervision was a discriminant variable for Internet addicts and, differently from the behavior of the variable in the original study (Teixeira et al., 2006), this educational practice seems to have acted more negatively for the research participants. It can be hypothesized that this practice is more associated with paternal control than with supervision, in view of the participants' mean age, who are entering the young adult phase (Ministério da Saúde, 2007). In addition, the father's educational practice of behavioral supervision could be associated in this case with high levels of the requirement construct (characterizing an authoritarian educational style), due to the family environment permeated by high family conflict rates, as observed through the different conflict variables that discriminate Internet addicts, in line with the study by Goulart (2012).

The conflicts/disagreements with the father equally play a discriminant role for Internet addiction. Nowadays, studies indicate greater paternal involvement with the children (Wagner, 2011). When compared to the mothers, however, the fathers still have a more peripheral position towards the children (Wagner et al., 2002) and, therefore, may display less skills to cope with conflict situations, showing less flexibility or adopting more coercive attitudes, mainly in more traditional families (when the father is more engaged in providing for the family and the mother in the other responsibilities linked to the children), which could explain the increase in conflicts and disagreements between fathers and children.

In addition to the parent-child conflicts, other conflicts linked to the parents' marital relationship also played a discriminant role for the Internet dependents. Specifically the feeling of threat dimension of the interparental conflict, characterized according to the CPIC when the child feels threatened by the interparental conflicts and fears the end of marriage as an outcome and, consequently, what his/her future will be like in view of this fact (Grych et al., 1992). As the research participants' mean age is about 20 years and as they belong to nuclear families, their parents' marriage may go back a long period; nevertheless, the hypothesis is raised that marital satisfaction levels are low, in view of the perceived threat of divorced according to the children. These results appoint that the conflicting relations between the parents of the study participants can be understood based on the spillover hypothesis, as their negative reflexes spill over to the children's mental health (Erel \& Burman, 1995).

Another variable associated to the marital relationship is the perceived content of interparental conflicts, characterized when the children perceive themselves as the reason why the parents fight (Grych et al., 1992). This result supports the findings by Goulart (2012) that disagreements about the children are the most prevalent, besides financial reasons according to the adolescents' perspective. In addition, the children's perception about them being the reason for the parents' conflict may indicate that contents supposedly exclusive to the marital relationship are not restricted to this subsystem, demonstrating fuzzy limits between the subsystems (Minuchin, 1990; Wagner, 2011).

Finally, the triangulation in the interparental conflict supports the role of the other triad variables in discriminating the youth's Internet addiction in this study. These results indicate that, according to the young people, their parents present high levels of marital conflict, often about them, which can happen because the unsolved disagreements between the couple can deviate towards the relation with the child.

Thus, Internet addiction can indicate the youth's perceived existence of an underlying marital conflict, expressed by disagreements about the children. This conflict, if explicit between the couple, could destabilize the marital union even further, which justifies these young people's feeling of threat that the parents will divorce. Hence, the tension the marital conflict produces loses its focus and centralizes in care for the child, which becomes the focus of attention, deviating from the original conflict (Minuchin, 1990). Consequently, the child's symptom causes an increase in educational practices with low levels of responsiveness and high levels of coercive control, provoking the increase in the levels of parent-child conflict, which longitudinally entails further symptoms, leading to further disagreement between the couple (Buehler \& Gerard, 2002; Erel \& Burman, 1995), with feedback to marital and family dynamics with low functionality levels.

The research results, based on a sample of young Brazilians, support international findings about the impact of family relations on Internet addiction especially the parents' marital relationship. Although most participants are in the young 
adult phase, the fact is highlighted that the children still feel influenced by their parents' conflicting marital relations.

Studies involving the marital relations' repercussions in the children's emotional and behavior problems are mostly focused on children. Nevertheless, these research results suggest that the effects seem to remain stable in the course of development. In addition, despite knowing that personal and personality factors are involved in young people's Internet addiction, these findings sustain the importance of preventive action, with a view to understanding and treating this possible new psychopathological condition, involving the entire family.

Future studies in the Brazilian population can contribute to a more precise understanding of this complex and multifaceted phenomenon, taking into account other relevant variables, such as co-parenthood. Qualitative research designs could offer indepth analyses of the young people's perceptions.

\section{References}

Abreu, C. N., Karam, R. G., Góes, D. S., \& Spritzer, D. T. (2008). Dependência de Internet e de jogos eletrônicos: Uma revisão [Internet and videogame addiction: A review]. Revista Brasileira de Psiquiatria, 30(2), 156167. doi:10.1590/S1516-44462008000200014

American Psychiatric Association. (2012). DSM-5 development. Retrieved from http://www.dsm5.org/ Pages/Default.aspx

Ang, R. P., Chong, W. H., Chye, S., \& Huan, V. S. (2012). Loneliness and generalized problematic Internet use: Parents' perceived knowledge of adolescents' online activities as a moderator. Computers in Human Behavior, 28(4), 1342-1347. doi:10.1016/j.chb.2012.02.019

Araújo, D. C. L., Calvano, L. A., Souza, E. F. L., Magalhães, E. J. M., Ricardo, C. S., Bastos, D. M. L., . . Araújo, F. S. (2010). Cleptomania; jogo patológico; compras compulsivas; dependência de Internet e de jogos eletrônicos: Aspectos atuais. [Kleptomania; Pathological Gambling; Compulsive Buying Disorder; Internet and Videogame Addiction: Current Aspects]. Neurobiologia, 73(1), 161-173.

Beard, K. W., \& Wolf, E. M. (2001). Modification in the proposed diagnostic criteria for Internet addiction. Cyber Psychology \& Behavior, 4(3), 377-383. doi:10.1089/109493101300210286

Benetti, S. P. C. (2006). Conflito conjugal: Impacto no desenvolvimento psicológico da criança e do adolescente. [Marital conflict: Impact on the psychological development of children and adolescents]. Psicologia: Reflexão e Crítica, 19(2), 261-268. doi:10.1590/S010279722006000200012

Bernedo Muñoz, I. M., Fuentes Rebollo, M. J., \& Fernández Molina, M. (2005). Percepción del grado de conflicto en familias adoptivas y no adoptivas. [Perception of the degree of conflict in adoptive and no adoptive families]. Psicothema, 17(3), 370-374.

Buehler, C., \& Gerard, J. M. (2002). Marital conflict, ineffective parenting, and children's and adolescents' maladjustment. Journal of Marriage and Family, 64(1), 78-92. doi:10.1111/j.1741-3737.2002.00078.x

Byun, S., Ruffini, C., Mills, J. E., Douglas, A. C., Niang, M., Stepchenkova, S., . . , Blanton, M. (2009). Internet addiction: Metasynthesis of 1996-2006 quantitative research. CyberPsychology \& Behavior, 12(2), 203-207. doi:10.1089/cpb.2008.0102

Centro de Estudos sobre as Tecnologias da Informação e Comunicação [Centre for Studies on Information and Communication Technologies]. (2013). TIC Domicílios. Retrieved from http://www.cetic.br/pesquisa/domicilios/ indicadores

Chen, S.-H., Weng, L.-I., Su, Y.-J., Wu, H.-M., \& Yang, P.F. (2003). Development of a Chinese Internet Addiction Scale and its psychometric study. Chinese Journal of Psychology, 45(3), 279-294.

Conti, M. A., Jardim, A. P., Hearst, N., Cordás, T. A., Tavares, H., \& Abreu, C. N. (2012). Avaliação da equivalência semântica e consistência interna de uma versão em português do Internet Addiction Test (IAT) [Evaluation of semantic equivalence and internal consistency of a Portuguese version of the Internet Addiction Test (IAT)]. Revista de Psiquiatria Clínica, 39(3), 106-110. doi:10.1590/S0101-60832012000300007

Cummings, E. M., \& Davies, P. T. (2011). Marital conflict and children: An emotional security perspective. New York, NY: Guilford.

Dell'Osso, B., Altamura, A. C., Allen, A., Marazziti, D., \& Hollander, E. (2006). Epidemiologic and clinical updates on impulse control disorders: A critical review. European Archives of Psychiatry and Clinical Neuroscience, 256(8), 464-475. doi:10.1007/s00406-006-0668-0

Dowling, N. A., \& Quirk, K. L. (2009). Screening for Internet dependence: Do the proposed diagnostic criteria differentiate normal from dependent Internet use? CyberPsychology \& Behavior, 12(1), 21-27. doi:10.1089/ cpb.2008.0162

Durkee, T., Kaess, M., Carli, V., Parzer, P., Wasserman, C., Floderus, B., . . . Wasserman, D. (2012). Prevalence of pathological Internet use among adolescents in Europe: Demographic and social factors. Addiction, 107(12), 2210-222. doi:10.1111/j.1360-0443.2012.03946.x

Erel, O., \& Burman, B. (1995). Interrelatedness of marital relations and parent-child relations: A meta-analytic review. Psychological Bulletin, 118(1), 108-132. doi:10.1037/0033-2909.118.1.108

Faugier, J., \& Sargeant, M. (1997). Sampling hard to reach populations. Journal of Advanced Nursing, 26(4), 790797. doi:10.1046/j.1365-2648.1997.00371.x

García Linares, M. C., Cerezo Rusillo, M. T., de la Torre Cruz, M. J., de la Villa Carpio Fernández, M., \& Casanova Arias, P. F. (2011). Prácticas educativas paternas y problemas internalizantes y externalizantes en adolescentes españoles [Parental educational practices and internalizing and externalizing problems in Spanish adolescents]. Psicothema, 23(4), 654-659. 
Goulart, V. R. (2012). Conflitos conjugais: A perspectiva dos filhos [Marital conflict: The children's perception] (Master's thesis). Retrieved from www.lume.ufrgs.br/ bitstream/handle/10183/72794/000884127.pdf

Goulart, V. R., \& Wagner, A. (2013). Os conflitos conjugais na perspectiva dos filhos. Arquivos Brasileiros de Psicologia, 65(3), 392-408.

Grych, J. H., Seid, M., \& Fincham, F. D. (1992). Assessing marital conflict from the child's perspective: The Children's Perception of Interparental Conflict Scale. Child Development, 63(3), 558-572. doi:10.2307/1131346

Hair J. F., Jr., Anderson, R. E., Tatham, R. L., \& Black, W. C. (2005). Análise multivariada de dados (A. S. San'Anna \& A. Chaves Neto, Trans., 5th ed.) Porto Alegre, RS: Artmed.

Instituto Brasileiro de Geografia e Estatística. (2012). Censo demográfico 2010: Famílias e domicílios: Resposta da amostra [Demographic Census 2010: Families and households: Response Sample]. Rio de Janeiro, RJ: IBGE. Retrieved from http://www.ibge.gov.br/home/ estatistica/populacao/censo2010/familias_e_domicilios/ default_familias_e_domicilios.shtm

Jiménez, A. P., \& Delgado, A. O. (2002). Comunicación y conflicto familiar durante la adolescencia [Communication and family conflict during adolescence]. Anales de Psicología, 18(2), 215-231. doi:10.6018/28421

Li, W., Garland, E. L., \& Howard, M. O. (2014). Family factors in Internet addiction among Chinese youth: A review of English and Chinese language studies. Computers in Human Behavior, 31, 393-411. doi:10.1016/j. chb.2013.11.004

Lin, C.-H., Lin, S.-L., \& Wu, C.-P. (2009). The effects of parental monitoring and leisure boredom on adolescents' Internet addiction. Adolescence, 44(176), 993-1004.

Liu, C.-Y., \& Kuo, F.-Y. (2007). A study of Internet addiction through the lens of the interpersonal theory. CyberPsychology \& Behavior, 10(6), 799-804. doi:10.1089/cpb.2007.9951

López Larrosa, S., Sánchez Souto, V., \& Ruíz de Alda, P. M. (2012). Los adolescentes y el conflicto interparental destructivo: Impacto en la percepción del sistema familiar y diferencias según el tipo de familia, la edad y el sexo de los adolescentes [Adolescents and destructive interparental conflict: Impact on the perception of the family system and differences by adolescents' type of family, age and sex]. Universitas Psychologica, 11(4), 1255-1262.

Luna Bernal, A. (2012). Funcionamiento familiar, conflictos con los padres y satisfacción con la vida de familia en adolescentes bachilleres [Family functioning, conflicts with parents and family life satisfaction in adolescent high-school students]. Acta Colombiana de Psicología, 15(1), 77-85.

Ministério da Saúde. Área de Saúde do Adolescente e do Jovem. (2007). Marco legal: Saúde, um direito de adolescentes [Legal framework: Health, a right for teens]. Brasília, DF: Ministério da Saúde. Retrieved from http://
bvsms.saude.gov.br/bvs/publicacoes/07_0400_M.pdf

Minuchin, S. (1990). Famílias: Funcionamento \& tratamento [Families: Functioning and treatment]. Porto Alegre, RS: Artmed.

Mosmann, C. P. (2007). A qualidade conjugal e os estilos educativos parentais [The marital quality and parental educational styles] (Doctoral dissertation). Retrieved from http://repositorio.pucrs.br/dspace/handle/10923/4768

Mosmann, C. P., Wagner, A., \& Sarriera, J. (2008). A qualidade conjugal como preditora dos estilos educativos parentais: O perfil discriminante de casais com filhos adolescentes. Psicologia, 22(2), 161-182.

Paiva, F. S., \& Ronzani, T. M. (2009). Estilos parentais e consumo de drogas entre adolescentes: Revisão sistemática. Psicologia em Estudo, 14(1), 177-183. doi:10.1590/S1413-73722009000100021

Parque, S. K., Kim, J. Y., \& Cho, C. B. (2008). Prevalence of Internet addiction and correlations with family factors among South Korean adolescents. Adolescence, 43(172), 895-909.

Pujol, C. C., Alexandre, S., Sokolovsky, A., Karam, R. G., \& Spritzer, D. T. (2009). Dependência de Internet: Perspectivas em terapia cognitivo-comportamental. Revista Brasileira de Psiquiatria, 31(2), 185-186. doi:10.1590/S1516-44462009000200019

Shapira, N. A., Lessig, M. C., Goldsmith, T. D., Szabo, S. T., Lazoritz, M., Gold, M. S., \& Stein, D. J. (2003). Problematic Internet use: Proposed classification and diagnostic criteria. Depression and Anxiety, 17(4), $207-$ 216. doi:10.1002/da.10094

Teixeira, M. A. P., Oliveira, A. M., \& Wottrich, S. H. (2006). Escalas de Práticas Parentais (EPP): Avaliando dimensões de práticas parentais em relação a adolescentes. Psicologia: Reflexão e Crítica, 19(3), 433-441. doi:10.1590/S0102-79722006000300012

Van Eijnden, R. J. J. M., Spijkerman, R., Vermulst, A. A., van Rooij, T. J., \& Engels, R. C. M. E. (2010). Compulsive Internet use among adolescents: Bidirectional parent-child relationships. Journal of Abnormal Child Psychology, 38(1), 77-89. doi:10.1007/s10802-009-9347-8

Wagner, A. (Org.). (2011). Desafios psicossociais da família contemporânea: Pesquisas e reflexões [Psychosocial challenges of the contemporary family: Research and reflections]. Porto Alegre, RS: Artmed.

Wagner, A., Falcke, D., Silveira, L. M. B. O., \& Mosmann, C. P. (2002). A comunicação em famílias com filhos adolescentes [The communication in families with adolescent children]. Psicologia em Estudo, 7(1), 75-80. doi:10.1590/S1413-73722002000100010

Weinstein, A., \& Lejoyeux, M. (2010). Internet addiction or excessive Internet use. The American Journal of Drug and Alcohol Abuse, 36(5), 277-283. doi:10.3109/009529 90.2010 .491880

Yen, J.-Y., Yen, C.-F., Chen, C.-C., Chen, S.-H., \& Ko, C.H. (2007). Family factors of Internet addiction and substance use experience in Taiwanese adolescents. 
CyberPsychology \& Behavior, 10(3), 323-329. doi:10.1089/cpb.2006.9948

Young, K. S. (1998). Internet addiction: The emergence of a new clinical disorder. CyberPsycholgy \& Behavior, 1(3), 237-244. doi:10.1089/cpb.1998.1.237

Young, K. S., \& Abreu, C. N. (Eds.). (2011). Dependência de Internet: Manual e guia de avaliação e tratamento [Internet addiction: Manual and evaluation and treatment guide] (M.

A. V. Veronese, Trans.). Porto Alegre, RS: Artmed.

Michele Terres-Trindade is a M.S. in Clinical Psychology from Universidade do Vale do Rio dos Sinos and Professor at Universidade Feevale.

Clarisse Pereira Mosmann has a Ph.D. in Psychology from Pontifícia Universidade Católica do Rio Grande do Sul and is a Professor at Universidade do Vale do Rio dos Sinos.

Received: Sep. 19, 2014

1st Revision: Jan. 10, 2015

2nd Revision: Mar. 17, 2015

Approved: Apr. 8, 2015

How to cite this article:

Terres-Trindade, M., \& Mosmann, C. P. (2015). Discriminant profile of young internet dependents: The role of family relationships. Paidéia (Ribeirão Preto), 25(62), 353-361. doi:10.1590/1982-43272562201509 